\title{
Pendugaan Neraca Air Spasial untuk Evaluasi Ketersediaan Sumberdaya Air Studi Kasus: Daerah Aliran Sungai Cerucuk, Pulau Belitung
}

\section{Spasial Water Balance Estimation for Evaluation of Water Resources Availability Case Study: Cerucuk Watershed, Belitung Island}

\author{
IDA NARULITA \\ Pusat Penelitian Geoteknologi Lembaga IImu Penegtahuan Indonesia \\ Kampus LIPI, JI. Sangkuriang, Bandung, 40135 \\ narulita_ida@yahoo.co.id
}

\begin{abstract}
Spatial water balance of Cerucuk Watershed, Belitung islands has been developed to evaluate water resource availability in terms of water resources sustainable management. The estimation of the monthly spatial water balance was carried out using SCS methods, soil water tension ( $p F)$ distribution and hydraulic conductivity ( $k$ ) differences done using Geographic Information Systems (SIG). The base data used in this study isdaily rainfall data from5 (five) different rainfall stations scattered in the study areawhich are owned by BMKG (2 units) and by palm oil plantations ( 3 units), Landsat 8 satellite imagery data of 2013, and soil and geological maps of Belitung island. The calculations showed that the surface water and shallow groundwater are available for the whole Cerucuk watershed. Shallow groundwater is available in every month along the year, even in the month of August the water is still highly available. But, the deep groundwater recharge is relatively small because the Cerucuk watershed composed ofgranite Tanjungpanformation that is almost totallyimpermeable. The groundwater aquifer was not found.The total rainfall of Cerucuk watershed will releasethrough evapotranspiration (36\%), flowing asrunoff (34\%), infiltration as shallow groundwater recharge (28\%) and infiltration as deep groundwater recharge $(1,7 \%)$. The result of the landuse type application model showed that the forest cover, plantations and dry land farming produced quite sufficient amount of recharged groundwater. But in the wetlands, settlements and mining areas, most of the rainfall flows as a runoff. This causes water shortages in the residential area during dry season.Control of the residential areas and preservation of the vegetated areas in the south area of Cerucuk watershed is necessary to ensure the water resources sustainability.
\end{abstract}

Keywords: water balance, spatial, SCS method, water resources availability.

\begin{abstract}
ABSTRAK
Neraca air spasial DAS Cerucuk, pulau Belitung telah dikembangkan untuk mengevaluasi ketersediaan sumberdaya air dalamrangka pengelolaan sumberdaya air yang berkelanjutan. Pendugaan neraca air spasial bulanan dilakukan dengan metoda SCS, distribusi tegangan pori dan perbedaan konduktivitas hidraulik berdasarkanpenggunaan Sistem Informasi Geografis (SIG). Data dasar yang digunakan yaitudata curah hujan harian dari 5 (lima) stasiun pencatat hujan yang berasal dari milik BMKG (2 stasiun) dan milik perkebunan kelapa sawit (3 stasiun), data citra satelit Landsat 8 tahun 2013, peta tanah dan peta geologi pulauBelitung. Hasil perhitungan menunjukkan bahwa air permukaan dan airtanah dangkal cukup tersedia untuk keseluruhan DAS Cerucuk. Airtanah dangkal tersedia pada setiap bulan sepanjang tahun,bahkan pada bulan Agustus ketersediaan air masih cukup banyak. Pengisian airtanah dalam relatif sedikit karena sebagian besar DAS Cerucuk tersusun oleh formasi granit Tanjungpandan yang hampir tidak memiliki kelulusan. Akifer airtanah dalam tidak ditemukan. Total curah hujan yang jatuh di DAS Cerucuk akan lepasmelalui evapotranspirasi (36\%), menjadi air larian (34\%), mengisi airtanah dangkal (28\%) dan mengisi airtanah dalam (1,7\%). Hasil penerapan model terhadap setiap jenis tutupan lahan memperlihatkan bahwa air hujan yang jatuh pada jenis tutupan lahan hutan, perkebunan dan pertanian lahan kering menghasilkan jumlah imbuhan airtanah dangkal cukup besar, sedangkan untuk lahan basah, pemukiman dan kolong area tambang sebagian besar mengalir sebagai air larian.Hal ini menyebabkandi daerah pemukiman pada musim kemarau dirasakan adanya periode defisit air.Pengendalian daerah pemukiman dan pelestarian daerah bervegetasi di selatan DAS Cerucuk sangat diperlukan untuk menjamin kelestarian sumberdaya air.
\end{abstract}

Kata kunci: neraca air, spasial, metode SCS, ketersediaan sumberdaya air. 


\section{PENDAHULUAN}

Kabupaten Belitung merupakan Kawasan Ekonomi Khusus (KEK) sektor pariwisata di Propinsi Kepulauan Bangka Belitung ${ }^{(1)}$. Hal tersebut menyebabkan di Kabupaten Belitung khususnya kota Tanjungpandan sedang mengalami kenaikkan pesat dalam aktivitas ekonomi dan pertumbuhan penduduk. Daerah Aliran Sungai (DAS) Cerucuk adalah salah satu DAS utama di Kabupaten Belitung, dimana kota Tanjungpandan sebagai ibukota kabupaten Belitung berada di dalam DAS ini ${ }^{(2)}$. Permasalahan sumberdaya air seperti kekeringan, banjir, dan kesulitan pemanfaatan sumberdaya air dan layanan air bersih terjadi di Kabupaten Belitung(3), khususnya di daerah urban. Hampir di setiap awal musim kemarau sumur warga dan hampir seluruh sungai atau aliran air serta kolong dan kolam penampungan mengalami penyusutan volume air yang begitu tajam. Sebaliknya pada saat musim hujan DAS Cerucuk di pulau Belitung mengalami permasalahan banjir akibat dari penggerusan dan sedimentasi dari DAS, serta faktor berubahnya fungsi lahan yang menyebabkan air tidak dapat meresap lagi ${ }^{(3)}$. Di sisi lain tekanan perubahan tataguna lahan yang sangat cepat, terutama tataguna lahan hutan menjadi perkebunan dan pemukiman mempengaruhi terjadinya curah hujan yang berpotensi mengakibatkan bencana banjir. Curah hujan yang merupakan sumber air utama di kota Tanjungpandan, Kabupaten Belitung selain dipengaruhi oleh angin musim, ITCZ, dan topografi, juga ada indikasi dipengaruhi oleh perubahan tutupan lahan $^{(4)}$. Penyebab utama permasalahan krisis air ini adalah karena sumberdaya air dan lahan telah dieksploitasi melebihi batas daya dukungnya ${ }^{(5)}$. Untuk menjamin ketersediaan sumberdaya air akibat pemanfaatan yang meningkat maka sumberdaya air dan lahan perlu dikelola dengan tepat. Pengelolaan sumberdaya air yang tepat harus didasarkan pada data ketersediaan air yang rinci dan terukur, dengan mempertimbangkan sebanyak mungkin faktor alam yang mempengaruhinya dimana meliputi aspek konservasi dan penggunaan $\operatorname{lahan}^{(6)}$. Menduga ketersediaan air di suatu daerah tidak mudah karena sumberdaya air merupakan fungsi dari ruang dan waktu dari banyak faktor alam seperti Hujan, Bentuk Wilayah, Geologi, Tanah dan Tutupan serta Penggunaan Lahan. Untuk itu ketersediaan air harus diduga berdasarkan fungsi ruang dan waktu, dalam bentuk neraca air spasial bulanan berdasarkan Sistem Informasi Geografi. Dengan adanya program Sistem Informasi Geografi (SIG), terbuka kemungkinan untuk menyimpan berbagai data faktor hidrologi secara kuantitatif dan memiliki acuan koordinat spasial untuk kemudian diintegrasikan ke dalam suatu operasi perhitungan $^{(5,7)}$.

Neraca air spasial bulanan dikembangkan dengan metoda SCS dimana air hujan yang turun di suatu tempat akan dipilah menjadi air larian, evapotranspirasi, imbuhan airtanah dangkal dan imbuhan airtanah dalam ${ }^{(5)}$. Imbuhan airtanah dangkal dan dalam yang merupakan salah satu hasil kuantifikasi dalam studi ini adalah parameter penting yang harus diketahui kuantitasnya dalam pengelolaan sumberdaya air yang berkelanjutan. Pengukuran air imbuhan secara langsung sangat sulit untuk dilakukan karena keberadaannya yang bervariasi dalam ruang dan waktu ${ }^{(8)}$. Estimasi neraca air spasial dilakukan dengan mempertimbangkan faktor curah hujan, tutupan lahan, tekstur tanah dan geologi sebagai akibat dari faktor-faktor ini dalam memainkan peranannya yang sangat penting pada imbuhan $\operatorname{airtanah}^{(9)}$

\section{BAHAN DAN METODE}

\subsection{Daerah penelitian}

Daerah Aliran Sungai (DAS) Cerucuk terletak di Kabupaten Belitung, Provinsi Kepulauan Bangka-Belitung. Secara geografis DAS Cerucuk terletak antara $107,6^{\circ}-107,9^{\circ}$ BT dan $2,6^{\circ}-2,9^{\circ} \mathrm{LS}$, dengan luas DAS sekitar 544 $\mathrm{km}^{2}$. Jumlah penduduk hasil estimasi pada tahun 2012 sebesar 163.871 jiwa $^{(10)}$. DAS Cerucuk berhulu di gunung Tajam, Kabupaten Belitung (ketinggian $500 \mathrm{~m} \mathrm{dpl}$ ) dan bermuara di kota Tanjungpandan ${ }^{(10)}$.

Daerah penelitian yaitu DAS Cerucuk dengan ketinggian $\pm 5 \mathrm{~m}$ dpl (di Tanjungpandan) dan dengan ketinggian $500 \mathrm{~m}$ dpl (di puncak gunung Tajam), dengan topografi yang bervariasi mulai dari dataran landai sampai dengan bergelombang. Sebagian besar (90\%) DAS Cerucuk merupakan daerah dataran dengan kemiringan < 8\%dengan ketinggian antara $0-25 \mathrm{~m} \mathrm{dpl,} 8 \%$ luas DAS Cerucuk mempunyai kemiringan antara 8 - 40\% dengan ketinggian 25 - $125 \mathrm{~m}$ dpl. Hanya 0,5\% DAS Cerucuk mempunyai kemiringan lebih dari $40 \%$ dengan ketinggian 125 - $500 \mathrm{~m} \mathrm{dpl}^{(11)}$.

DAS Cerucuk mempunyai rerata curah hujan bulanan sebesar 280 - $521 \mathrm{~mm} /$ bulan sedangkan rerata curah hujan tahunannya sebesar $3000 \mathrm{~mm}^{(11)}$. Hari hujan bulanan pada tahun 2013 berkisar antara 8 - 28 hari per bulannya.Temperatur udara pada tahun 2013 yang tercatat di stasiun BMKG adalah $24,9^{\circ} \mathrm{C}$ $27^{\circ} \mathrm{C}$. 


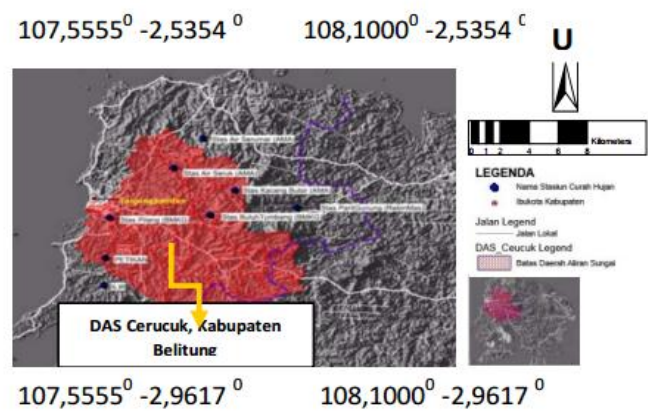

Gambar 1. Lokasi penelitian dan sebaran lokasi stasiun pencatat curah hujan

\subsection{Data Dasar dan Metodologi Penelitian}

Data yang digunakan dalam penelitian ini meliputi data curah hujan harian dari 5 (lima) stasiun pencatat hujan yang tersebar di DAS Cerucuk. Dua (2) stasiun milik BMKG yaitu stasiun Buluh Tumbang dengan periode 1981 2013 dan stasiun Pilang dengan periode 1996 2013, Satu stasiun hujan milik PT. Palmindo yaitu Petikan dengan periode 2009 - 2012, dua stasiun hujan milik PT. AMA (Air Seruk dan Kacang Butor) dengan periode 2005 - 2012. Lokasi stasiun pencatat hujan dapat dilihat pada Gambar 1. Data Satelit Landsat 8 tahun 2013 daerah Belitung diunduh dari situs resmi USGS. Peta tanah digital digunakan untuk menyusun peta sebaran kelulusan tanah (permeabilitas tanah).Peta Geologi digital digunakan untuk menyusun sebaran nilai konduktifitas hidrolik batuan. Penelitian ini mengikuti model konseptual pada Gambar 2. di bawah ini.

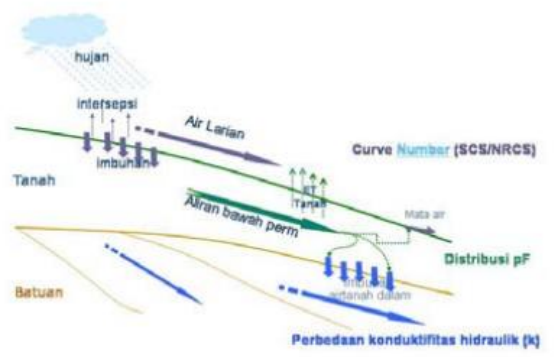

Gambar 2. Komponen aliran pada daur air dan metoda yang diadopsi pada penelitian ini untuk pemilahannya ${ }^{(5)}$.

Neraca air spasial bulanan dikembangkan dengan metoda SCS. Prinsip dari perhitungan ini berdasarkan perhitungan pada tiga tahap pemilahan. Perhitungan pertama adalah memilah air hujan yang jatuh di suatu tempat menjadi air larian, intersepsi yang kemudian menguap kembali, dan air yang mengimbuh ke dalam tanah. Proses perhitungan pada tahap pemilahan pertama ini dilakukan dengan metoda
Curve Number ${ }^{(12,13)}$. Perhitungan kedua adalah air yang mengimbuh ke dalam tanah kemudian dipilah kembali menjadi air evapotranspirasi dan air perkolasi yang dilakukan dengan metoda distribusi tegangan pori tanah $(\mathrm{pF})$. Sedangkan perhitungan ke tiga yaitu memilah air perkolasi menjadi imbuhan air tanah dan aliran bawah permukaan yang kemudian keluar sebagai mata air. Proses pemilahan untuk perhitungan ketiga inidilakukan berdasarkan perbedaan konduktivitas hidraulik (k) antara tanah dan batuan.

Jumlah dan arah pergerakan komponenkomponen aliran air ini ditentukan oleh sejumlah faktor penting yaitu faktor curah hujan, topografi, jenis tanah, jenis vegetasi dan tutupan lahan serta jenis batuan ${ }^{(14)}$. Sejumlah faktor penting yang dihitung dalam neraca air ini bervariasi dalam ruang dan waktu maka untuk menguantifikasi setiap komponennya perlu dikembangkan metode kuantifikasi secara spasial dan temporal ${ }^{(5)}$.

Distribusi intensitas hujan spasial disusun menggunakan data curah hujan dari 5 (lima) stasiun hujan yang tersebar di daerah kajian. Pemetaan distribusi hujan dilakukan dengan cara isohyet karena bagian hulu DAS Cerucuk merupakan daerah dengan kemiringan lereng yang bervariasi. Berdasarkan data yang diperoleh persamaan korelasi terbaik antara ketinggian tempat dan curah hujan bulanan terlebih dahulu ditentukan ${ }^{(4)}$. Korelasi antara curah hujan dan hari hujan ditentukan kemudian setiap bulannya. Persamaan korelasi curah hujan dan ketinggian lokasi studi kemudian diplotkan pada peta DEM yang diturunkan dari peta topografi skala 1:25000. Nilai intensitas hujan pada setiap titik (lokasi) ditentukan dengan menggunakan persamaan curah hujan dan hari hujan yang mempunyai korelasi terbaik.

Peta tematik tataguna lahan diperoleh melalui pengolahan citra satelit Landsat 8 tahun 2013 pada DAS Cerucuk, Pulau Belitung. Pengolahan data citra satelit Landsat 8 band optik dilakukan dengan metode klasifikasi unsupervised ${ }^{(11)}$.

Distribusi kelulusan tanah (pemeabilitas tanah) diturunkan dari peta tekstur tanah berdasarkan peta tanah daerah penelitian. Nilai permeabilitas yang dipakai adalah nilai tengah dari kisaran nilai pada setiap kelas tekstur. Prosentase pori kapiler pada setiap kelas tekstur tanah ditetapkan pula ${ }^{(15)}$.

Distribusi konduktifitas hidraulik batuan (k) diturunkan dari peta geologi. Setiap jenis batuan dianggap memiliki nilai $k$ yang seragam yang besarnya sama dengan nilai rerata aritmetik kisaran $\mathrm{k}$ jenis batuan dimaksud ${ }^{(16)}$. 


\subsection{Data masukan}

Proses imbuhan sangat ditentukan oleh proses interaksi antara curah hujan, geologi, tekstur tanah, dan tutupan lahan ${ }^{(17)}$. Sehingga untuk menduga jumlah air hujan yang mengimbuh (imbuhan) menggunakan metoda SCS dan memanfaatkan SIG. Dengan demikian, data yang diperlukan tersebut disiapkan dalam bentuk peta. Data masukan dalam penelitian ini meliputi peta curah hujan, peta tutupan lahan tahun 2013, peta distribusi kelulusan tanah dan kelas hidrologi tanah, serta peta geologi DAS Cerucuk.

\subsubsection{Peta curah hujan}

Peta curah hujan disusun dengan metode isohyet karena bagian hulu DAS Cerucuk merupakan daerah dengan topografi berbukit ${ }^{(4)}$. Peta curah hujan bulanan diturunkan menjadi peta intensitas hujan bulanan dan peta frekuensi hujan yang terjadi setiap bulannya. Peta curah hujan bulanan dapat dilihat pada Gambar 3 .

Berdasarkan Gambar 3. dapat diketahui bahwa rerata curah hujan di DAS Cerucuk pada bulan Juni berkisar $163 \mathrm{~mm}$, bulan Februari berkisar $243 \mathrm{~mm}$ dan pada bulan Desember berkisar $521 \mathrm{~mm}$. Curah hujan dengan elevasi lebih tinggi akan mendapatkan curah hujan lebih banyak daripada di daerah elevasi lebih rendah. Hujan tertinggi terjadi di daerah Gunung Tajam di bagian Timur DAS Cerucuk.

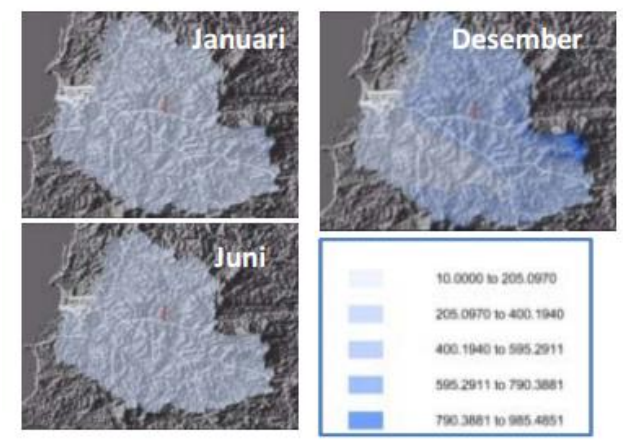

Gambar 3. Distribusi spasial curah hujan bulanan DAS Cerucuk pulau Belitung ${ }^{(4)}$.

\subsubsection{Peta Tutupan Lahan tahun 2013 DAS Cerucuk}

Peta tutupan lahan DAS Cerucuk tahun 2013 diperoleh dari hasil klasifikasi citra satelit Landsat 2013 menggunakan metode klasifikasi unsupervised ${ }^{(11)}$. Pada Gambar 4 dan Tabel 1 menunjukkan bahwa sebagian besar (54\%) tutupan lahan DAS Cerucuk berupa ilalang dan pertanian lahan kering. Luasan kedua seluas $21 \%$ berupa hutan dan $8 \%$ luasannya berupa perkebunan. Daerah pemukiman menempati
6,6\% dari luas DAS Cerucuk akan tetapi pemukiman ini terkonsentrasi di Tanjungpandan dan di sekitar alur sungai Cerucuk.

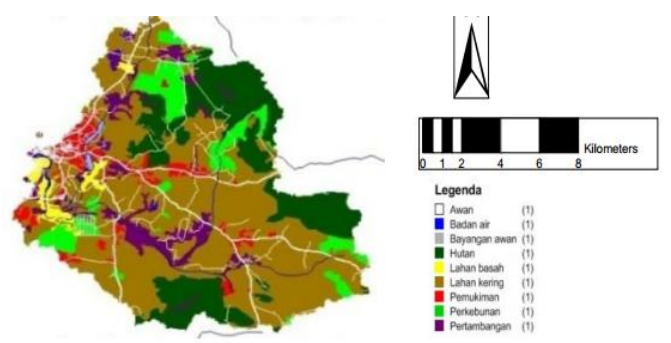

Sumber : Hasil klasifikasi tahun $2014^{(11)}$.

Gambar 4. Peta Tutupan Lahan DAS Cerucuk

Tabel 1. Luas Tutupan lahan hasil pengolahan data satelit

\begin{tabular}{lcc}
\hline Jenis Tutupan Lahan & $\begin{array}{c}\text { Luas 2013 } \\
\left(\mathrm{km}^{2}\right)\end{array}$ & $\begin{array}{c}\text { Luas } \\
(\%)\end{array}$ \\
\hline Badan air & 3.108 & 0.57 \\
Hutan & 116.564 & 21.42 \\
Lahan basah & 12.447 & 2.29 \\
Pertanian lahan kering & 291.193 & 53.53 \\
dan ilalang & & \\
Pemukiman & 35.884 & 6.59 \\
Perkebunan & 45.110 & 8.29 \\
Pertambangan & 39.662 & 7.29 \\
\hline
\end{tabular}

Sumber : Hasil klasifikasi tahun $2014^{(11)}$

\subsubsection{Peta Distribusi kelulusan tanah dan kelas hidrologi tanah DAS Cerucuk}

Peta distribusi kelulusan tanah yang diturunkan dari Peta Satuan Lahan dan Tanah Lembar Belitung Sumatera ${ }^{(18)}$ dapat dilihat pada Gambar 5. Kelulusan tanah adalah kemampuan tanah untuk melalukan (atau dilalui) air. Untuk kuantifikasi sumberdaya air, kelulusan tanah perlu diketahui karena sangat menentukan jumlah air hujan yang masuk kedalam tanah serta lamanya air tertahan di dalam tanah. Semakin tinggi nilai permeabilitas tanah maka kemampuan tanah dalam melalukan air semakin besar. Tabel 2. adalah klasifikasi kelulusan tanah di DAS Cerucuk. Dari Gambar 5. dan Tabel 2. menunjukkan bahwa sebagian besar (> 54\%) tanah di DAS Cerucuk mempunyai kelulusan agak lambat, kemudian $17 \%$ luasan mempunyai kelulusan tanah sedang. Hanya 3\% dari luasan DAS Cerucuk mempunyai kelulusan tanah agak cepat dan cepat. 

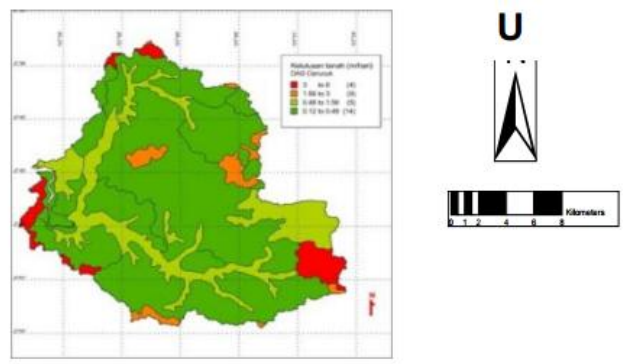

(Sumber :Hasil analisis(Narulita et al., 2014)(11) dari Peta Satuan Lahan dan Tanah Lembar Belitung Sumatera (Puslittanak, 1990) $^{(18)}$

\section{Gambar 5. Peta distribusi kelulusan tanah DAS Cerucuk, pulau Belitung}

Peta kelas hidrologi tanah di DAS Cerucuk diturunkan dari peta distribusi kelulusan tanah (Gambar 5.) yang digunakan untuk menentukan proporsi air larian dan air infiltrasi yang besarannya ditentukan oleh tekstur tanah dan laju infiltrasi tanah ${ }^{(15)}$. Dari peta kelas hidrologi tanah dan Tabel 3. dapat ditunjukkan bahwa lebih dari $54 \%$ luas DAS Cerucuk mempunyai kelas hidrologi tanah $\mathrm{D}$, dimana laju infiltrasinya $<1 \mathrm{~mm} / \mathrm{jam}$ dengan tekstur tanah lempung berliat dan lempung berdebu.

Tabel 2. Klasifikasi Kelulusan Tanah (Permeabilitas tanah)

\begin{tabular}{lccc}
\hline $\begin{array}{l}\text { Klasifikasi } \\
\text { kelulusan } \\
\text { tanah }\end{array}$ & $\mathrm{cm} / \mathrm{jam}$ & $\mathrm{m} /$ hari & $\begin{array}{c}\text { Rerata } \\
(\mathrm{m} / \mathrm{hari})\end{array}$ \\
\hline Sangat Cepat & $>25$ & $>6$ & 8 \\
Cepat & $12.5-25$ & $3-6$ & 4,5 \\
Agak Cepat & $6.5-12.5$ & $1.56-3$ & 2,28 \\
Sedang & $2-6.5$ & $0.48-1.56$ & 1.02 \\
Agak Lambat & $0.5-2$ & $0.12-0.48$ & 0.3 \\
Lambat & $0.1-0.5$ & $0.024-0.12$ & 0.072 \\
Sangat & $<0.1$ & $<0.02$ & 0.005 \\
Lambat & & & \\
\hline Sumber :Arsyad, S., $2010^{(19)}$ & &
\end{tabular}

Tabel 3. Kelompok Hidrologi Tanah

\begin{tabular}{|c|c|c|}
\hline $\begin{array}{l}\text { Kelompok } \\
\text { Tanah }\end{array}$ & $\begin{array}{l}\text { Laju } \\
\text { Infiltrasi } \\
\text { (mm/jam) }\end{array}$ & Tekstur Tanah \\
\hline $\mathrm{A}$ & $8-12$ & $\begin{array}{l}\text { Pasir, Pasir berlempung, } \\
\text { lempung berpasir }\end{array}$ \\
\hline B & $4-8$ & Lempung berdebu, lempung \\
\hline $\mathrm{C}$ & $1-4$ & Lempung pasir berliat \\
\hline D & $<1$ & $\begin{array}{l}\text { Lempung berliat, lempung } \\
\text { berdebu }\end{array}$ \\
\hline
\end{tabular}

\subsubsection{Peta Geologi DAS Cerucuk, pulau Belitung}

Gambar 6. menunjukkan geologi DAS Cerucuk disusun oleh batuan terobosan (intrusi), batuan alluvial, dan batuan sedimen ${ }^{(20)}$. Batuan alluvial menempati bagian Barat DAS Cerucuk (pantai). Batuan sedimen yaitu Formasi Tajam dan Formasi Kelapakampit menempati seluruh bagian Selatan DAS Cerucuk. Batuan terobosan (intrusi) yaitu batuan Granit Tanjungpandan menempati seluruh bagian Utara DAS Cerucuk. Sebagian besar (57\%) batuan di DAS Cerucuk adalah Granit Tanjungpandan, Batupasir Formasi Tajam 11,75\%, Batuan sedimen Formasi Kelapakampit 30,22 \% dan batuan alluvial yang mampu meresapkan air tanah hanya $1 \%$ saja. Setiap satuan geologi mempunyai nilai konduktivitas hidraulik yang nilainya diambil dari Tabel Konduktivitas hidraulik ${ }^{(20)}$.

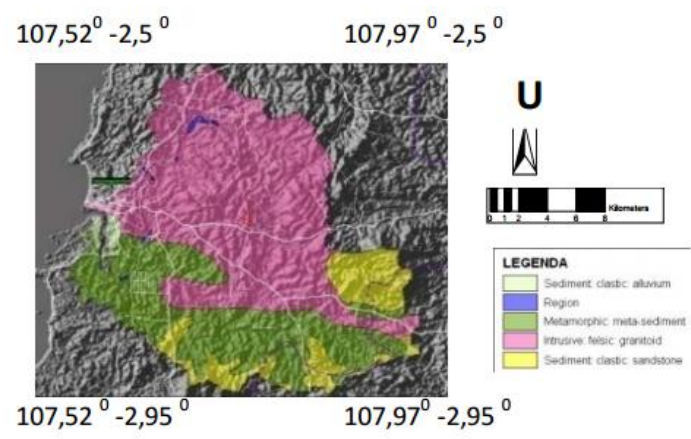

Gambar 6. Peta Geologi DAS Cerucuk

Nilai Konduktivitas hidraulik batuan granit yang menempati $57 \%$ dari luas DAS Cerucuk adalah $0,00000001 \mathrm{~m} /$ detik $^{(21)}$. Ini menunjukkan bahwa air hujan sangat sulit meresap dalam batuan granit, sehingga akifer di daerah ini tidak berkembang dengan baik. Hampir $80 \%$ batuan di wilayah ini kurang baik meluluskan air.

\section{HASIL PENELITIAN DAN PEMBAHASAN}

\subsection{Estimasi neraca air berdasarkan Tutupan Lahan}

Tutupan lahan utama yang ada di DAS Cerucuk berupa pertanian lahan kering, hutan, perkebunan, pemukiman, pertambangan, dan lahan basah. Komponen neraca air untuk setiap tutupan lahan dibahas dalam tulisan ini yaitu air larian, evapotranspirasi, resapan airtanah dangkal dan resapan airtanah dalam. Sebelum membahas distribusi resapan airtanah dangkal dan dalam, terlebih dahulu akan dibahas distribusi air larian dan evapotranspirasi. Karena air hujan yang turun sebelum masuk ke dalam tanah sebagai resapan airtanah dangkal dan dalam terlebih dahulu terpilah menjadi air larian, intersepsi ${ }^{(11,12)}$ dan evapotranspirasi ${ }^{(14)}$. Berdasarkan peta curah hujan bulanan DAS Cerucuk, rerata curah hujan bulanan di DAS Cerucuk tergolong tinggi, dimana rerata curah hujan bulanan terendah pada bulan Juni sebesar $163 \mathrm{~mm}$ dan tertinggi bulan Desember 
berkisar $521 \mathrm{~mm}$. Pada Gambar 7. menunjukkan hasil perhitungan neraca air bulanan yang disajikan dalam bentuk peta airlarian, evapotranspirasi, resapan airtanah dangkal dan resapan airtanah secara spasial dan temporal untuk seluruh DAS Cerucuk. Pada peta air larian DAS Cerucuk (Gambar 7.) menunjukkan bahwa sebagian besar DAS Cerucuk memproduksi air larian kecuali pada daerah dengan kelulusan tanah besar dimana evapotranspirasinya tinggi sehingga curah hujan yang turun di daerah tersebut habis untuk evapotranspirasi. Penggambaran neraca air setiap satuan tutupan lahan dalam bentuk grafik disajikan pada Gambar 8. Pada Gambar 8 dapat dilihat air larian tertinggi diproduksi oleh daerah pemukiman (>50\% air hujan menjadi air larian) akibat tertutupnya permukaan tanah oleh aspal dan bangunan. Kemudian yang terbanyak berikutnya adalah lahan basah (49\%) dan area pertambangan (45\%). Produksi air larian rendah terjadi pada daerah hutan (26\%), perkebunan $(26 \%)$ dan pertanian lahan kering (32\%). Pada Gambar 9. dapat kita lihat bahwa proporsi air hujan menjadi air larian cukup besar di daerah yang tidak/kurang bervegetasi, sedangkan di daerah bervegetasi proporsi airlarian relatif kecil. Di sini menunjukkan bahwa vegetasi mempunyai fungsi menahan air hujan sehingga memperkecil jumlah proporsi air larian.

Pada Gambar 7. dan Gambar 8. dapat kita lihat nilai evapotranspirasi tertinggi terjadi di tutupan lahan hutan (41.6\%), kemudian adalah daerah perkebunan $(38.5 \%)$ dan berikutnya adalah daerah pertanian lahan kering (36\%). Sedangkan evapotranspirasi terendah terjadi di daerah pemukiman (18\%). Nilai evapotranspirasi terdiri dari dua komponen, yaitu evaporasi dan transpirasi. Pada tutupan lahan hutan dan perkebunan nilai evapotranspirasi tinggi adalah nilai transpirasi dari tanaman. Sedangkan pada pertanian lahan kering nilai evapotranspirasi tinggi akibat dari evaporasi tanah karena tutupan vegetasinya yang tidak rapat sehingga masih banyak area lahan yang terbuka yang memperbesar nilai evaporasi $^{10}$. Gambar 7. dan Gambar 8. menunjukkan neraca air total DAS Cerucuk dalam satu tahun di tahun 2013. Hasilnya menunjukkan jumlah air hujan yang menjadi evapotranspirasi tertinggi terjadi pada daerah dengan banyak vegetasi yaitu pada tutupan lahan hutan, perkebunan dan pertanian lahan kering, sedangkan produksi evapotranspirasi terendah terjadi di daerah pemukiman. Meskipun nilai evapotranspirasi dari vegetasi tinggi akan tetapi pada waktu yang bersamaan vegetasi juga mempunyai peran di dalam menahan air larian yang jumlahnya bisa jadi lebih besar dari nilai evapotranspirasi.
Pengisian air permukaan dan airtanah dangkal cukup tersedia untuk keseluruhan DAS Cerucuk. Khususnya untuk tahun 2010 ketika curah hujan tahunan relatif tinggi, air tersedia pada setiap bulan di sepanjang tahun, bahkan pada bulan-bulan Januari sampai Agustus ketersediaan air berlimpah. Pendugaan neraca air bulanan untuk keseluruhan DAS Cerucuk menunjukkan bahwa total curah hujan tahun 2010 yang jatuh di DAS Cerucuk 36\% nya akan menguap kembali ke udara sebagai evapotranspirasi, 34\% akan menjadi air larian, $28 \%$ akan mengisi airtanah dangkal dan hanya $1.7 \%$ yang akan mengisi airtanah dalam (Gambar 7). Untuk keseluruhan DAS Cerucuk pengisian imbuhan airtanah terbesar terjadi pada bulan Mei - Agustus.

Pengisian airtanah dangkal terjadi banyak di tutupan lahan hutan, perkebunan dan pertanian lahan kering (Gambar 7., 8 dan 9.). Sedangkan daerah pemukiman dan pertambangan resapan airtanah dangkalnya sangat kecil (Gambar 8. dan Gambar 9.) Pengisian airtanah dangkal terbanyak terjadi di bagian Selatan, Timur dan Utara DAS Cerucuk (Gambar 7.). Hal ini karena curah hujan yang terjadi setelah dikurangi evapotranspirasi dan air larian masih tersisa untuk diresapkan menjadi imbuhan airtanah dangkal. Pengisian airtanah dalam di DAS Cerucuk relatif sedikit, karena sebagian besar DAS Cerucuk tersusun oleh granit formasi Tanjungpandan yang hampir tidak memiliki kelulusan dan batuan malihan formasi kelapa Kampit yang kelulusannya sangat kecil (Lihat Gambar 6.). Hanya sebagian kecil batuan wilayah DAS Cerucuk yang memiliki akifer tanah dalam, yaitu pada batuan alluvial yang berada di DAS Cerucuk bagian Barat dan pada batupasir formasi Tajam yang terletak di DAS Cerucuk bagian Selatan (Gambar 6.). Keberadaan air tanah dalam di DAS Cerucuk akan mudah di peroleh pada batuan alluvium, kemampuan air melewati batuan di daerah aluvium ini sebesar $3 \times 10^{-5} \mathrm{~m} /$ detik, hal ini berkaitan permeabilitas dari batuan sedimen klastik aluvium cukup tinggi, dibandingkan dengan permebalitas batuan lainnya di DAS Cerucuk. Aluvium berada di sisi barat DAS Cerucuk, dengan luas $\pm 5,35$ $\mathrm{km}^{2}(0,01 \%$ dari luas DAS Cerucuk). Pengisian airtanah dalam terjadi di atas tutupan lahan hutan, perkebunan, pertanian lahan kering. Pada tutupan lahan basah juga terjadi pengisian airtanah dalam karena air hujan yang turun di atasnya masuk ke dalam batuan alluvial yang mampu meresapkan air hujan dengan baik (Lihat Gambar 7, 10 dan 11). 

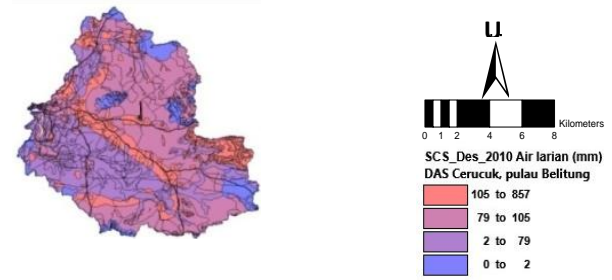

Distribusi Air Larian DAS Cerucuk DAS Cerucuk Desember 201́u
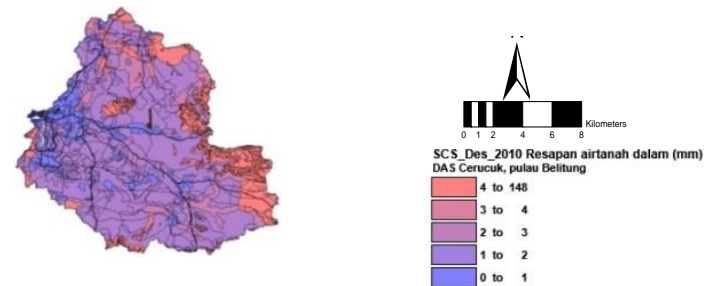

Distribusi Evapotranspirasi DAS Cerucuk Desember 2013
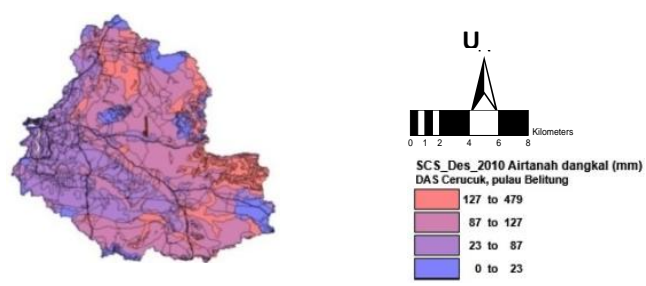

Distribusi resapan airtanah dangkal DAS Cerucuk bulan Desember 2013
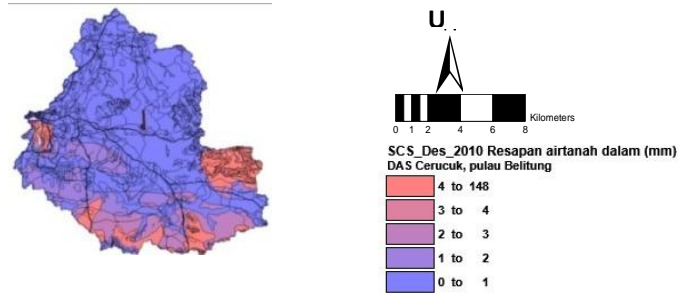

Distribusi resapan airtanah dalam DAS Cerucuk bulan Desember 2013

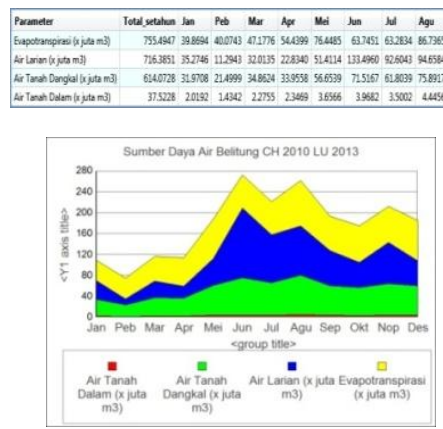

Gambar 7. Neraca Air Spasial dan Temporal seluruh DAS Cerucuk, pulau Belitung

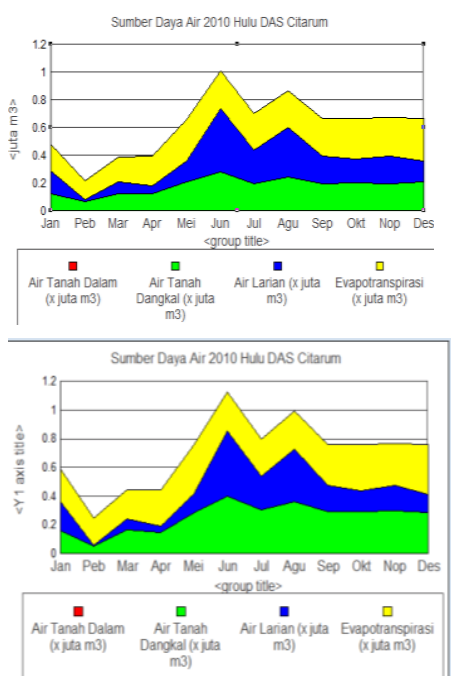

Tutupan Lahan Hutan

Tutupan

Lahan

Perkebunan

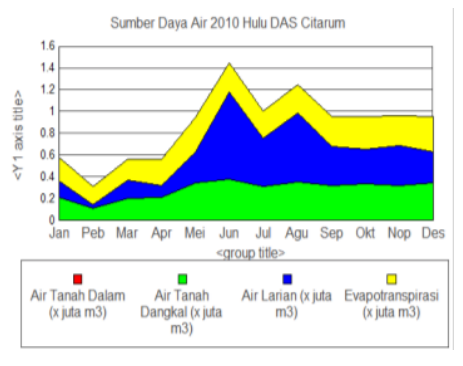

Tutupan

Lahan

Lahan

kering

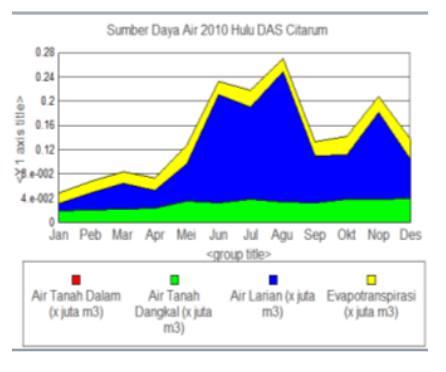

Tutupan Lahan

Lahan basah

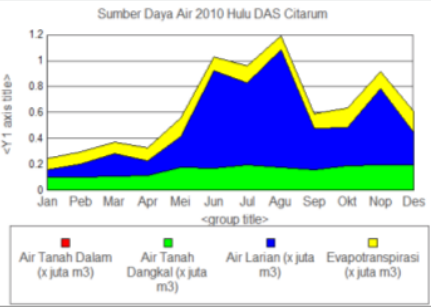

Tutupan

Lahan

Pemukiman

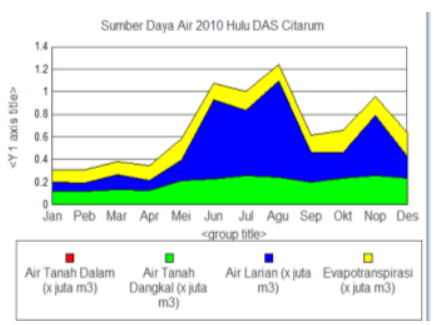

Tutupan

Lahan

Kolong/bekas

tambang

Gambar 8. Neraca Air bulanan setiap satuan tutupan lahan DAS Cerucuk, pulau Belitung 


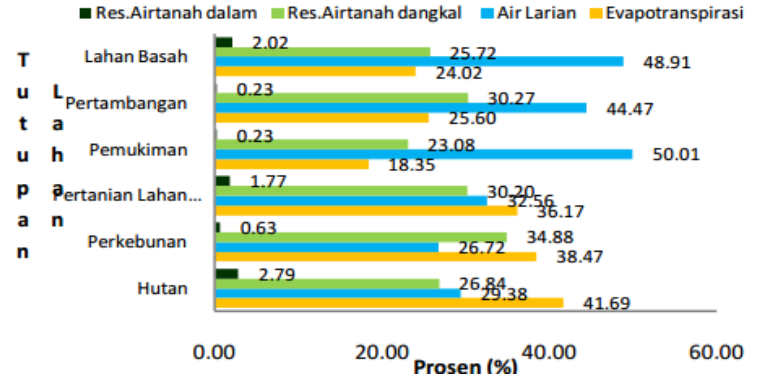

Gambar 9. Prosentase air hujan yang menjadi komponen neraca air DAS Cerucuk, pulau Belitung tahun 2013 berdasarkan tutupan lahan

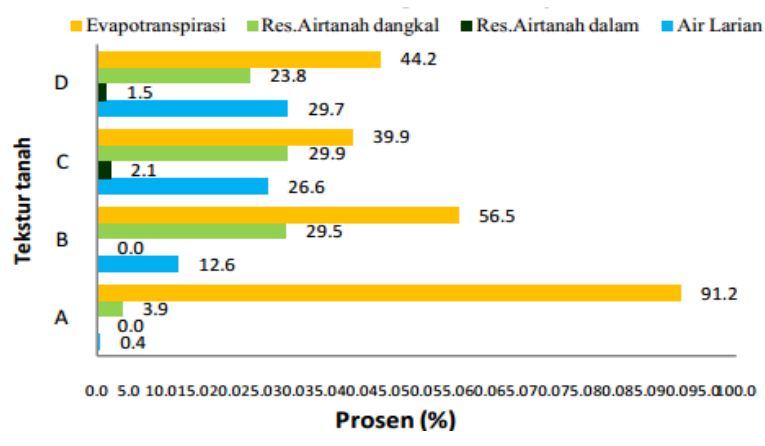

Gambar 10.Neraca air dan prosentase air hujan menjadi komponen neraca air tahun 2013 berdasarkan tekstur tanah di DAS Cerucuk,pulau Belitung

\subsection{Estimasi neraca air berdasarkan Tekstur tanah}

Pada daerah studi tipe tekstur tanah terdiri dari 4 kelompok yaitu tipe tekstur tanah A, B, C dan $D$ (Lihat tabel 3). Pada peta air larian, produksi air larian terendah adalah pada tekstur tanah tipe A dimana pada daerah tipe A dicirikan dengan tekstur tanah pasir, pasir berlempung, dan lempung berpasir. Pada daerah ini terjadi evaporasi dari tanah yang cukup tinggi, sehingga curah hujan yang jatuh di atasnya habis untuk proses evaporasi tanah (Gambar 8 dan Gambar 10.). Pada Gambar 10. dapat kita lihat bahwa $90 \%$ air hujan yang jatuh pada daerah tipe tekstur tanah A, $90 \%$ digunakan untuk proses evaporasi tanah. Tipe tanah $\mathrm{C}$ dan $\mathrm{D}$ berpotensi memproduksi air larian dan evapotranspirasi dalam jumlah besar, akan tetapi tipe tekstur tanah ini juga berpotensi terjadi pengisian airtanah dangkal dan airtanah dalam (Gambar 13.) karena curah hujan yang jatuh di atas tekstur tanah tipe ini sebagian dapat ditahan sehingga air hujan yang berpotensi bisa meresap sebagai pengisian airtanah dangkal dan airtanah dalam apabila geologinya mampu meresapkan air. Produksi air larian nilainya besar pada tipe tanah $C$ dan $D$ karena tekstur tanah tipe $C$ dan $D$ menempati area yang paling luas di DAS Cerucuk, dan secara umum seluruh DAS Cerucuk berpotensi memproduksi air larian (Gambar 6 dan Gambar 7). Pada tekstur tanah $C$ dan $D$ produksi evapotranspirasi juga besar yang diakibatkan oleh tutupan lahan di atas tanah tipe $C$ dan $D$ berupa pertanian lahan kering dan hutan.

\subsection{Estimasi neraca air berdasarkan Jenis Batuan}

Pada Gambar 11. dapat terlihat secara jelas bahwa resapan air tanah dalam cukup baik diproduksi oleh batuan aluvial yang berada di bagian Barat DAS Cerucuk dan batuan pasir Formasi Tajam di bagian selatan DAS Cerucuk, pulau Belitung (Gambar 6.). Sedangkan resapan airtanah dangkal hampir diproduksi oleh semua jenis batuan termasuk batuan granit. Akan tetapi batuan granit yang bisa meresapkan air hujan di DAS Cerucuk ini adalah batuan granit yang telah lapuk.

Permasalahan sumberdaya air yang terjadi di Kabupaten Belitung telah diuraikan pada makalah Hariyanto, A., dkk ${ }^{(3)}$ yaitu banjir dan kekeringan serta perubahan tutupan lahan yang tidak terkendali dimana Kabupaten Belitung memerlukan pengelolaan sumberdaya air untuk mengantisipasi kelangkaan air di masa depan. Pengelolaan sumberdaya air untuk daerah dengan permasalahan seperti di pulau Belitung ini pengalokasian sumberdaya air yang lebih rinci dan terukur yang didasarkan pada faktor Hujan, Bentuk Wilayah, Geologi, Tanah dan Tutupan serta Penggunaan Lahan sangat diperlukan dan pendekatan dengan cara spasial dan kuantitatif tampak sesuai diterapkan untuk mengelola sumberdaya air ${ }^{(8,22)}$.

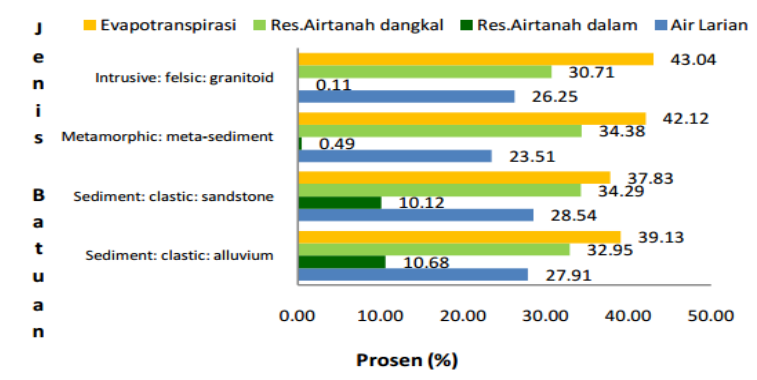

Gambar 11.Neraca air dan prosentase air hujan menjadi komponen neraca air tahun 2013 berdasarkan jenis batuan di DAS Cerucuk, pulau Belitung

Banjir di Kabupaten Belitung khususnya di DAS Cerucuk bisa dikurangi dengan melakukan penampungan air dengan pemanfaatan kolong dan pembangunan penampungan air di bagian 
tengah dari DAS Cerucuk yang mempunyai produktifitas air larian tinggi, misalnya daerah di sekitar bandara untuk menahan aliran permukaan sehingga bencana banjir bisa dikurangi. Air larian yang tertampung bisa dimanfaatkan untuk memenuhi kebutuhan air di saat musim kemarau tiba untuk menyambung ketersediaan air pada periode defisit air. Pengendalian tutupan lahan di bagian Selatan dan Timur DAS Cerucuk sangat diperlukan karena daerah ini mempunyai potensi menyimpan air hujan sebagai airtanah dalam.

\section{KESIMPULAN}

Berdasarkan hasil estimasi neraca air spasial di DAS Cerucuk dapat diperoleh beberapa informasi penting untuk evaluasi ketersediaan air bagi pengelolaan sumberdaya air di DAS Cerucuk yaitu: Air permukaan dan airtanah dangkal cukup tersedia untuk keseluruhan DAS Cerucuk. Pengisian air tanah dangkal terjadi di setiap bulannya sehingga air tersedia pada setiap bulan di sepanjang tahun, bahkan pada bulan-bulan Januari sampai Agustus ketersediaan air berlimpah. Meski demikian, pengisian airtanah dalam relatif sedikit, karena sebagian besar DAS Cerucuk tersusun oleh granit formasi Tanjungpandan yang hampir tidak memiliki kelulusan dan batuan malihan formasi kelapa Kampit yang kelulusannya sangat kecil. Hanya sebagian kecil batuan wilayah DAS Cerucuk yang memiliki akifer tanah dalam, yaitu pada batupasir formasi Tajam yang terletak di bagian Selatan dan batuan alluvial yang posisinya di dekat pantai Barat DAS Cerucuk.

Hasil penerapan model untuk estimasi neraca air terhadap setiap jenis tutupan lahan (Gambar 8. dan Gambar 9. ) memperlihatkan bahwa pada jenis-jenis tutupan lahan hutan, perkebunan dan pertanian lahan kering menghasilkan jumlah airtanah dangkal cukup besar, sedangkan untuk lahan basah, pemukiman dan tambang atau kolong sebagian besar air hujan mengalir sebagai air larian. Sedangkan pada estimasi neraca air terhadap satuan tekstur tanah menunjukkan bahwa tekstur tanah tipe A sebagian besar air hujan yang turun digunakan untuk evaporasi tanah sehingga produksi evapotranspirasi di tipe tanah ini besar. Sedangkan pada tipe tanah B, C dan $D$ air hujan yang jatuh dapat tertahan dan meresap sebagai pengisian airtanah dangkal. Estimasi neraca air pada tipe batuan menunjukkan pengisian air tanah dalam terjadi pada terjadi pada batuan alluvial dan batuan pasir formasi Tajam yang terletak di bagian Barat dan Selatan DAS Cerucuk.

Pada makalah ini telah dilakukan estimasi neraca air spasial berdasarkan faktor curah hujan, tutupan lahan, tekstur tanah dan geologi (jenis batuan) dimana faktor faktor ini memainkan peranan sangat penting dalam imbuhan airtanah ${ }^{(5)}$. Dengan estimasi neraca air ini diharapkan kita akan memahami peran dari curah hujan, tutupan lahan, tekstur tanah dan jenis batuan di lokasi penelitian untuk menentukan pengelolaan sumberdaya air yang tepat.

Curah hujan, tekstur tanah dan jenis batuan memainkan peranan penting dalam proses imbuhan tanah akan tetapi faktor-faktor ini merupakan faktor yang tidak bisa dikendalikan oleh manusia, hanya faktor tutupan lahan yang bisa dikendalikan. Untuk menjamin ketersediaan sumberdaya air secara terus menerus diperlukan pemilihan strategi yang tepat dalam menentukan perubahan penggunaan lahan dalam pengelolaan sumberdaya air yang berkelanjutan di DAS Cerucuk. Pelestarian daerah bervegetasi dan penanaman vegetasi di bagian Selatan DAS Cerucuk sangat penting untuk dilakukan, mengingat pengisian airtanah dalam hanya terjadi di daerah ini. Selain itu diperlukan pengendalian pengembangan daerah pemukiman karena hujan yang jatuh di daerah pemukiman, $50 \%$ air hujan tersebut berpotensi menjadi air larian yang bisa menjadi penyebab banjir. Pembangunan penampungan air dan pemanfaatan bekas kolong tambang (kolong tua) di bagian tengah DAS Cerucuk diharapkan dapat mengendalikan aliran permukaan pada musim hujan dan dimanfaatkan untuk memenuhi kebutuhan air di saat musim kemarau tiba untuk menyambung ketersediaan air pada periode defisit air.

\section{PERSANTUNAN}

Penulis mengucapkan terima kasih kepada LIPI yang telah mendanai penelitian ini melalui Program Unggulan LIPI Korsub. Ketahanan Air, Daya Saing Wilayah dan masyarakat pesisir. Bapak Ronny (Sekretaris Badan Lingkungan Hidup Daerah, Kab.Belitung Barat) beserta staf, dan Bapak Hermanto (Kepala BAPPEDA Kab.Belitung) yang telah mendukung kelancaran pelaksanaan penelitian.Ucapan terima kasih juga penulis sampaikan kepada Prof. Dr.Ir.M.R.Djuwansah dan Prof. Dr.Wahyoe Soepri Hantoro, yang telah memberikan masukan pada penulisan makalah ini dan rekan Arief Rahmat M.T, Rahmawati Rahayu M.T. dan Hari Rahyu Wibowo S.T sebagai anggota tim dalam penelitian ini.

\section{DAFTAR PUSTAKA}

1. Anonim, (2016), Peraturan Pemerintah Republik Indonesia No .6, Tahun 2016. 
2. Anoinim, (2015), Belitung Dalam Angka. ISSN :0215-4005. Katalog BPS / BPS Catalogue: 1102001.1902. BPS Kabupaten Belitung.296 pp.

3. Hariyanto, A., \& K. H Iskandar, (2015), Kajian Identifikasi Potensi dan Permasalahan Sumberdaya air (Studi Kasus: Kabupaten Belitung). Planologi: Jurnal Perencanaan Wilayah dan Kota, 2(11).

4. Narulita, I., (2016), Distribusi spasial dan temporal Curah Hujan di DAS Cerucuk, Pulau Belitung. Jurnal Riset dan Pertambangan, Vol. 26 No. 2: 141 - 154.

5. Djuwansah, M. R., dan I. Narulita, (2011), Aplikasi Sistem Informasi Geografi untuk menduga kuantitas komponen sumberdaya air bulanan secara spasial dengan metode CN-NRCS, tegangan airtanah dan konduktivitas hidraulik di hulu DAS Citarum.Jurnal RISET Geologi dan Pertambangan, 21(2): 89-103.

6. Black P. E., (1996), Watershed Hydrology. Lewis Publishers, London-New York.

7. Luijten, J. C., J. W Jones, and E.B. Knapp, 2000, Spatial soil water balance model and GIS Hydrological tools. International Consortium For Agricultural System Application. Agricultural and Biological Engineering-Univ. of Florida.

8. Healy, R. W., (2010), Estimating groundwater recharge. Cambridge University Press.

9. Zomlot, Z., B. Verbeiren, M., Huysmans, and O. Batelaan, (2015), Spatial distribution of groundwater recharge and base flow: Assessment of controlling factors. Journal of Hydrology: Regional Studies, 4: 349-368.

10. Anonim, (2011), Belitung dalam Angka. BAPPEDA kab.Belitung dengan BPS Kabupaten Belitung.

11. Narulita, I., M. Djuwansah, Tj.A.Soeprapto, R. Rahayu,dan H.R. Wibowo, (2014),
Laporan Akhir Kumulatif Kegiatan Kompetitif LIPI Tahun Anggaran 2012 - 2014.

12. Mc. Cuen R.H., (1982), A Guide to hydrologic analyses using SCS methods. Prentice Hall Publ.

13. Chow V.T., D.R. Maidment and L.W. Mays., (1988), Applied Hydrology. Mc. Graw Hill co.

14. Tilahun, K., and B.J. Merkel, ,(2009), Estimation of groundwater recharge using a GIS-based distributed water balance model in Dire Dawa, Ethiopia. Hydrogeology journal, 17(6): 1443-1457.

15. Chamayou H., and J.P. Legros., (1989), Les bases physiques, chimiques et mineralogiques de la science du sols. Presses universitaire de France - Paris.

16. R.A and J.A. Cherry.,(1979), Groundwater. Prentice Hall Publ.

17. De Vries, J. J., and I. Simmers, (2002), Groundwater recharge: an overview of processes and challenges. Hydrogeology Journal, 10(1): 5-17.

18. Anonim, (1990), Peta Satuan Lahan dan Tanah LembarBelitung Sumatera skala 1:250.000.Pusat PenelitianTanah dan Agroklimat. Bogor.

19. Arsyad, S., (2010), Konservasi Tanah \& Air, IPB Press.

20. Baharuddin dan Sidarta.,(1995), Geological Map Of the Belitung Sheet, Sumatera (1212, 1213, 1312, 1313) Scale $1: 250.000$, Geological Research and Development Centre, Bandung

21. Freeze, R.A. J.A. Cherry 1979. Groundwater New Jersey: Prentice - Hall.

22. Djuwansah R., dan I. Narulita (2006), Neraca Air Spasial di bagian Hulu Das Citarum sebagai Basis Data Anggaran Air. Jurnal Teknologi Indonesia. Volume 29, No.1. ISSN 0126-1533. 